\title{
Silver Nanoparticle Formation in Different Sizes Induced by Peptides Identified within Split-and-Mix Libraries**
}

\author{
Kirsten Belser, Tünde Vig Slenters, Conelious Pfumbidzai, Grégory Upert, Laurent Mirolo, \\ Katharina M. Fromm,* and Helma Wennemers*
}

Silver nanoparticles (AgNPs) are becoming increasingly important for manifold applications in, for example, imaging, catalysis, electronics, and the development of antimicrobial coatings. ${ }^{[1-3]}$ The formation of AgNPs is typically accomplished by chemical reduction or irradiation of $\mathrm{Ag}^{+}$ions with visible light in the presence of additives, such as polymers or surfactants, which induce the formation of AgNPs and stabilize the NPs. ${ }^{[1,2]}$ Recently, peptides bearing functional groups that coordinate to $\mathrm{Ag}^{+}$ions have become popular as additives. ${ }^{[4-8]}$ Their large structural and functional diversity also renders peptides attractive for the controlled formation of AgNPs of defined sizes, which still presents a challenge to date. Since the rational design of peptides that induce metal NP formation is difficult, combinatorial approaches are attractive for the identification of suitable peptides. ${ }^{[7,8]} \mathrm{We}$ envisaged that colorimetric on-bead screening of split-andmix libraries could be a particularly powerful tool that would allow the testing of diverse libraries, which contain both natural and unnatural amino acids. ${ }^{[9]}$ The typical size- and shape-dependent coloration of $\mathrm{AgNPs}^{[1]}$ was anticipated to allow for a facile identification of active library members.

Herein, we introduce the use of combinatorial split-andmix libraries for the identification of peptides that are capable of inducing the formation of AgNPs. In conjunction with scanning electron microscopy (SEM) studies, we also demonstrate that the method allows for the identification of certain types of peptides that induce the formation of AgNPs of specific sizes.

[*] Dipl.-Chem. T. Vig Slenters, L. Mirolo, Prof. Dr. K. M. Fromm Department of Chemistry, University of Fribourg

Chemin du Musée 9, 1700 Fribourg (Switzerland)

Fax: (+41) 26-300-9738

E-mail: katharina.fromm@unifr.ch

Dr. K. Belser, C. Pfumbidzai, Dr. G. Upert, Prof. Dr. H. Wennemers Department of Chemistry, University of Basel

St. Johanns-Ring 19, 4056 Basel (Switzerland)

Fax: $(+41)$ 61-267-0976

E-mail: helma.wennemers@unibas.ch

Homepage: http://www.chemie.unibas.ch/ wennemer/index.html

[**] K.B. and T.V.S. contributed equally to this work. Support from Bachem, the Swiss National Science Foundation, the NCCR NANO, FriMat, and the RTN "REVCAT" by the European Union is gratefully acknowledged. We thank G. Morson, M. Düggelin, and D. Mathys of the ZMB Basel and J. S. Agustsson, Dr. M. Calame, and Prof. Dr. C. Schönenberger for help in recording the SEM images. H.W. thanks Bachem for an endowed professorship.
We started our investigations by testing the members of peptide library 1 for their ability to induce AgNP formation in the presence of either light or the chemical reducing agent sodium ascorbate (Figure 1a). Within the library, the amino acids serine (Ser), aspartic acid (Asp), histidine (His), and tyrosine (Tyr), bearing functional groups that were envisaged for $\mathrm{Ag}^{+}$ion coordination, were employed in positions AA1 and AA2 (Figure 1). Tyr was included in the library as it is a
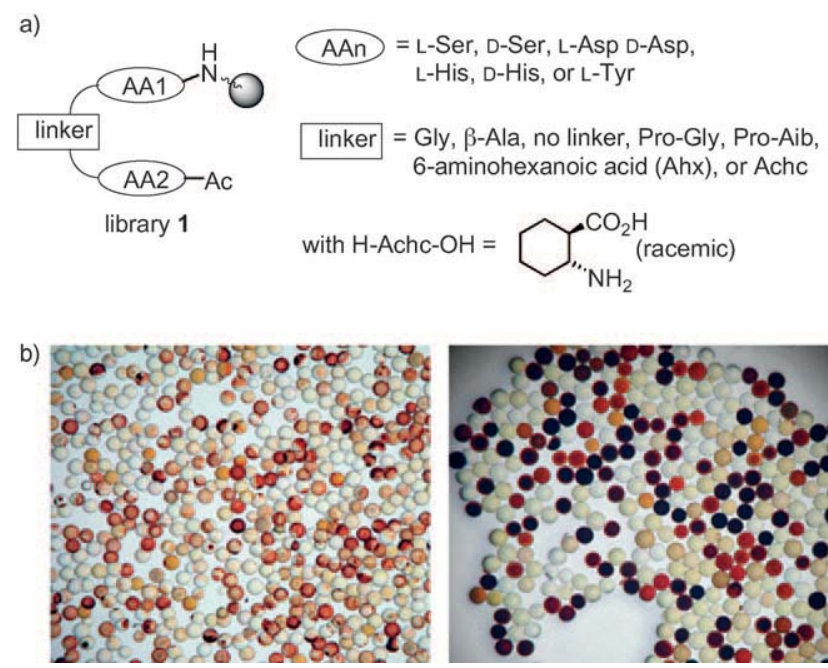

Figure 1. a) General structure of peptide library 1. b) AgNP formation within the combinatorial assay of 1 complexed to $\mathrm{Ag}^{+}$ions, followed by treatment with light (left) and sodium ascorbate (right).

well-known photoactive residue. ${ }^{[6]}$ Linkers of varying flexibility and geometry were used to connect the amino acids in order to allow for diverse spatial arrangements of their sidechain functional groups. trans-2-Aminohexanoic acid (Achc), Pro-Aib (Aib = aminoisobutyric acid) and Pro-Gly were chosen as turn-inducing linkers, and 6-aminohexanoic acid $(\mathrm{Ahx})$ and $\beta$-alanine as flexible linkers. The library was prepared by encoded ${ }^{[10]}$ split-and-mix synthesis ${ }^{[11]}$ on TentaGel resin by utilizing seven different linkers and seven different $\mathrm{L}$ - and $\mathrm{D}$-amino acids in positions AA1 and AA2, hence the library consisted maximally of $7^{3}=343$ different peptides (Figure 1a). Amino acid couplings were performed by following the standard Fmoc/ $t \mathrm{Bu}$ protocol for peptide synthesis using $\mathrm{HBTU} / i \mathrm{Pr}_{2} \mathrm{NEt}$ as the coupling reagent and piperidine for Fmoc deprotections (Fmoc $=9$-fluorenylmethyloxycarbonyl, $\mathrm{HBTU}=O$-(benzotriazol-1-yl)- $N, N, N^{\prime}, N^{\prime}-$ tetramethyluronium).

The library was then incubated with an aqueous solution of $\mathrm{AgNO}_{3}(0.05 \mathrm{M})$, washed with water to remove unbound 
$\mathrm{Ag}^{+}$ions, and irradiated with visible light (electric lamp). ${ }^{[12]}$ After $8 \mathrm{~h}$, approximately $5 \%$ of the beads had turned dark red, which is a typical color of AgNPs (Figure 1b, left). ${ }^{[13]}$ These results therefore suggest that the peptides on the red beads bind to $\mathrm{Ag}^{+}$ions and induce the formation of AgNPs upon irradiation with light. This hypothesis was confirmed by SEM studies, which clearly demonstrate the formation of AgNPs on the colored beads. Even more remarkable results were obtained when a solution of the chemical reductant sodium ascorbate was added to library $\mathbf{1}$ that had been complexed with $\mathrm{Ag}^{+}$ions. Within five minutes, several beads became colored and, notably, distinctly different colors ranging from yellow and light orange to dark red were observed (Figure $1 \mathrm{~b}$, right). Different colors are indicative of AgNPs of different sizes ${ }^{[1]}$ thus, this result suggests that different peptides within the library induce the formation of AgNPs of different sizes upon chemical reduction of the $\mathrm{Ag}^{+}$ ions.

Isolation of several of the colored beads from both assays and analysis of the peptides on them revealed the following main consensus sequences:

\section{AgNP formation by reduction of $\mathrm{Ag}^{+}$ions with light: Ac-His-Achc-Tyr-resin Ac-Ser-Achc-Tyr-resin Ac-Tyr-Achc-Ser-resin}

$\mathrm{AgNP}$ formation by reduction of $\mathrm{Ag}^{+}$ions with sodium ascorbate: $\mathrm{red} /$ dark orange Ac-His-X-His-resin beads

Ac-His-X-Asp-resin Ac-Asp-X-His-resin Ac-His-X-Tyr-resin Ac-Tyr-X-His-resin Ac-His-X-Ser-resin Ac-Ser-X-His-resin

yellow/light orange Ac-Asp-X-Asp-resin beads

Ac-Ser-X-Tyr-resin

Ac-Tyr-X-Ser-resin

Ac-Asp-X-Ser-resin

Ac-Ser-X-Asp-resin

$(\mathrm{X}=$ random linker $)$

Most of the peptides identified in the assay by the lightinduced reduction of $\mathrm{Ag}^{+}$ions contain the photoactive amino acid Tyr connected to either His or Ser by a rigid, turninducing linker (most commonly Achc), but also Pro-Aib or Pro-Gly, see the Supporting Information for a list of all sequences).${ }^{[14]}$ Different peptide sequences were identified in the assay using sodium ascorbate for the reduction of $\mathrm{Ag}^{+}$ ions to AgNPs. In this case, the red beads bear a His residue together with any of the other amino acids employed in the library. Peptides on yellow beads consist of either two Asp residues or combinations of Ser and Tyr, as well as Asp and Ser. Essentially any linker was found, suggesting that the relative orientation of the two amino acids is not crucial for their activity. In both assays, no pronounced selectivity for Lor D-configured amino acids was observed.
We then evaluated the AgNP-forming properties of several of the identified peptides, both resin-bound and in the solution phase. For the experiments with immobilized peptide, peptides $\mathbf{2 a - 8 a}$ were resynthesized on TentaGel (TG) resin. Peptides $2 \mathbf{a}-\mathbf{4 a}$ were identified only in the assay that used light for the reduction of $\mathrm{Ag}^{+}$ions, whereas all peptides were hits in the assay that used chemical reduction.

Ac-D-His-Achc-L-Tyr-TG (2 a)

Ac-D-Ser-Achc-L-Tyr-TG (3 a)

Ac-L-Tyr-Achc-D-Ser-TG (4 a)

Ac-L-His-Ahx-L-Asp-TG (5 a)

Ac-L-His-Pro-Gly-L-Asp-TG (6 a)

Ac-L-Ser-Ahx-L-Tyr-TG (7 a)

Ac-L-Ser-Pro-Gly-L-Tyr-TG (8 a)

In a procedure analogous to that of the combinatorial screening assays, the beads were incubated with a solution of $\mathrm{AgNO}_{3}$, washed with water to remove excess $\mathrm{Ag}^{+}$ions, and then irradiated with light for $8 \mathrm{~h}$ or treated with sodium ascorbate for $5 \mathrm{~min}$. In the presence of light, beads with peptides 2a-4 turned red or dark orange, whereas beads with peptides 5a and 6a remained colorless (see the Supporting Information for images). Beads with peptides $7 \mathbf{a}$ and $\mathbf{8 a}$, which have a flexible linker between the amino acids Ser and Tyr, became slightly orange upon irradiation but not nearly as dark as the beads with peptides $3 \mathbf{a}$ and $\mathbf{4} \mathbf{a}$ with the rigid linker Achc. These results verified the selectivities observed in the combinatorial assay. They also underlined the importance of a linker with a well-defined conformation in Tyr/His- or Tyr/ Ser-containing peptides for effective AgNP formation using light to reduce the $\mathrm{Ag}^{+}$ions. ${ }^{[15]}$ Analysis of the beads using $\mathrm{X}$ ray powder diffraction further verified the formation of AgNPs on beads with peptides $2 \mathbf{a}-\mathbf{4 a}$. SEM images revealed that the AgNPs derived from, for example, peptide $\mathbf{2 a}$, are highly ordered crystals with a pyramidal shape and an average size of $400 \mathrm{~nm}$ (Figure 2).

AgNP formation occurred within minutes after the addition of sodium ascorbate to the silver-complexed solid phase bound peptides $\mathbf{2 a - 8 a}$. As expected from the combinatorial assays, AgNP formation was induced by each of the examined peptides, however, NPs with distinctly different colors were generated. ${ }^{[16]}$ Beads with peptides $2 \mathbf{a}, 5 \mathbf{a}$, and $\mathbf{6 a}$ consisting of His together with Asp or Tyr turned red, whereas beads with peptides $\mathbf{3 a}, \mathbf{4 a}, 7 \mathbf{a}$, and $\mathbf{8 a}$ with $\mathrm{Ser} / \mathrm{Tyr}$
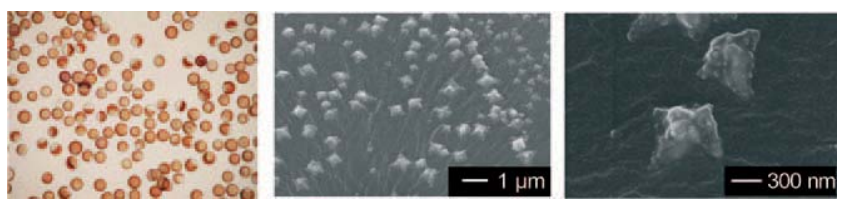

Figure 2. Microscopic (left) and SEM images (center and right) of AgNPs formed on the solid-supported peptide AC-D-His-Achc-L-Tyr-TG (2) after complexation with $\mathrm{Ag}^{+}$ions and irradiation with light. 
combinations showed a yellow coloration regardless of the linker between the amino acids. The differences in color correlate with the amount of $\mathrm{Ag}^{+}$ions that are complexed by peptides $\mathbf{2} \mathbf{a}-\mathbf{8 a}$, as shown in $\mathrm{Ag}^{+}$ion uptake studies. ${ }^{[17]}$ The more intense the color of the AgNPs on the beads, the more $\mathrm{Ag}^{+}$ions are bound to the immobilized peptide. SEM analyses of the bead-bound AgNPs showed that the red color corresponds to NPs with an average diameter of approximately $50 \mathrm{~nm}$ that can agglomerate to larger assemblies of up to $200 \mathrm{~nm}$. AgNPs on the yellow colored beads are significantly smaller, with an average diameter of approximately $10 \mathrm{~nm}$ (Figure 3). This result demonstrates that
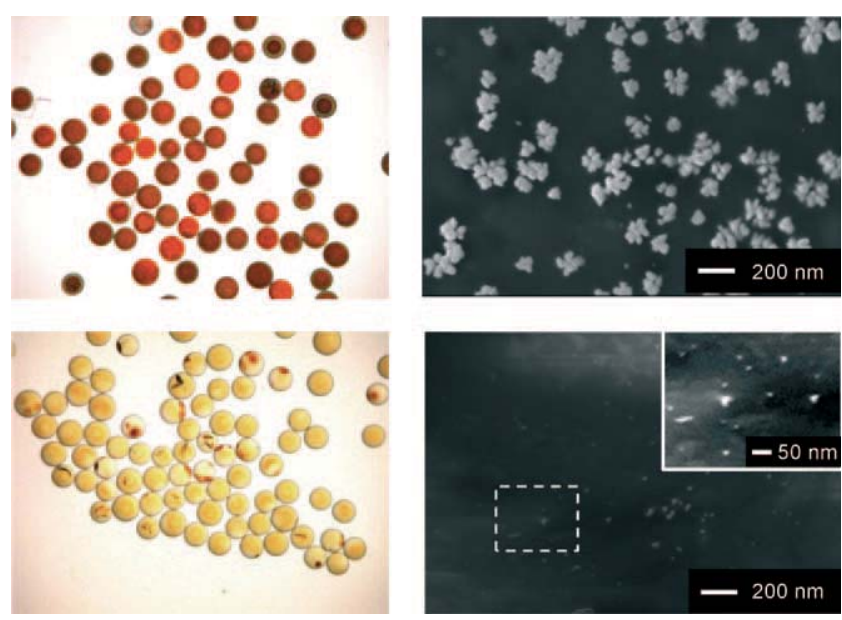

Figure 3. Microscopic (left) and SEM images (right) of AgNPs formed on solid-supported peptide AC-L-His-Ahx-L-Asp-TG (5 a, top) and AC-LSer-Ahx-L-Tyr-TG (7a, bottom) after complexation with $\mathrm{Ag}^{+}$ions and incubation with sodium ascorbate.

different peptides induce the selective formation of AgNPs of different sizes.

Regardless of the method used for their generation, the solid-phase-bound AgNPs proved to be stable for months. In comparison with the AgNPs generated from $2 \mathbf{a}-\mathbf{4 a}$ by light irradiation, the NPs generated by the reduction of $\mathrm{Ag}^{+}$ions with sodium ascorbate are amorphous, which is most likely due to their significantly faster formation compared to those formed by using light to initiate the reduction of the $\mathrm{Ag}^{+}$ions.

To analyze whether the identified peptides are also able to induce the formation of AgNPs in solution phase, peptides Ac-L-His-Ahx-L-Asp- $\mathrm{NH}_{2}$ (5b) and Ac-L-His-Pro-Gly-LAsp- $\mathrm{NH}_{2}$ (6b), were prepared. Upon mixing aqueous solutions of peptides $\mathbf{5 b}$ and $\mathbf{6 b}$ with substoichiometric amounts of $\mathrm{AgNO}_{3}$ (0.1 equivalents), followed by the addition of sodium ascorbate ( 0.12 equivalents), the solutions turned yellow and orange, respectively. These colors are indicative of solutions containing AgNPs. This is supported by UV/Vis spectroscopic studies that revealed absorption maxima at $408 \mathrm{~nm}$ typical for AgNPs (Figure 4). Thus, peptides $\mathbf{5} \mathbf{b}$ and 6b allow for the generation and stabilization of AgNPs both when bound to a solid support and in the solution phase.

In conclusion, we have shown that on-bead screening of split-and-mix libraries is a powerful tool for the identification of peptides that induce the formation of AgNPs. The method
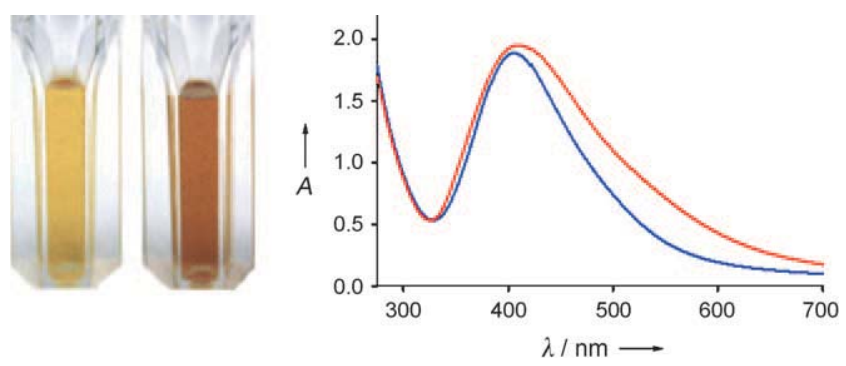

Figure 4. AgNP formation induced in aqueous solutions of peptides Ac-L-His-Ahx-L-Asp-NH $\mathrm{N}_{2}$ (5b, left image) and Ac-L-His-ProGly-L-Asp$\mathrm{NH}_{2}$ (6 $\mathbf{b}$, right image), and UV/Vis spectra of $\mathbf{5} \mathbf{b}$ (blue) and $\mathbf{6} \mathbf{b}$ (red) after $5 \mathrm{~h}$.

is general, and allows for the identification of peptides (and other compounds that can be accessed by a split-and-mix library approach) that generate $\mathrm{AgNPs}$ from $\mathrm{Ag}^{+}$ions when using either light or a chemical reducing agent. It led not only to the identification of simple tripeptides with nanoparticleforming properties that would have been difficult to predict rationally, but also revealed peptide motifs that generate AgNPs with distinctly different sizes. Moreover, the study illustrates how structural and functional modifications within peptides allow for the tuning of their nanoparticle-forming properties.

\section{Experimental Section}

General procedure for the combinatorial assays: Approximately $10 \mathrm{mg}$ of the library ${ }^{[12]}$ were suspended in an aqueous solution of $\mathrm{AgNO}_{3}(0.05 \mathrm{M}, 660 \mu \mathrm{L}$, ca. 6 equiv), sonicated for $5 \mathrm{~min}$ and allowed to incubate for another $10 \mathrm{~min}$. After washing with deionized water $(5 \times 1 \mathrm{~mL})$, the beads were either irradiated with an electric lamp for $8 \mathrm{~h}$ (light reduction assay) or incubated with a solution of sodium ascorbate $(0.05 \mathrm{M}, 660 \mu \mathrm{L}$, ca. 6 equiv) for $5 \mathrm{~min}$ (chemical reduction assay) before washing with deionized water $(5 \times 1 \mathrm{~mL})$. The combinatorial screening assays were evaluated using a light microscope, single beads were isolated and the peptide sequences analyzed. ${ }^{[10]}$ Approximately 30 beads from each assay were analyzed to obtain a statistically relevant result (see the Supporting Information).

[1] For reviews, see: a) I. Pastoriza-Santos, L. M. Liz-Marzán, J. Mater. Chem. 2008, 18, 1724-1737; b) C. J. Murphy, A. M. Gole, S. E. Hunyadi, J. W. Stone, P. N. Sisco, A. Alkilany, B. E. Kinard, P. Hankins, Chem. Commun. 2008, 544-557; c) N. L. Rosi, C. A. Mirkin, Chem. Rev. 2005, 105, 1547-1562; d) K. Aslan, J. Zhang, J. R. Lakowicz, C. D. Geddes, J. Fluoresc. 2004, 14, 391-399; e) A. Roucoux, J. Schulz, H. Patin, Chem. Rev. 2002, 102, $3757-$ 3778; f) R. C. N. Rao, G. U. Kulkarni, P. J. Thomas, P. P. Edwards, Chem. Soc. Rev. 2000, 29, 27-35; g) A. Henglein, Chem. Rev. 1989, 89, 1861-1873.

[2] For reviews, see: a) J. A. Dahl, B. L. S. Maddux, J. E. Hutchison, Chem. Rev. 2007, 107, 2228-2269; b) D. D. Evanoff Jr. , G. Chumanov, ChemPhysChem 2005, 6, 1221-1231. 
[3] a) P. S. Brunetto, K. M. Fromm, Chimia 2008, 62, 249-252; b) T. Vig Slenters, I. Hauser-Gerspach, A. U. Daniels, K. M. Fromm, J. Mater. Chem. 2008, 18, 5359-5362.

[4] For a general review on peptide-directed metal NP formation, see: M. B. Dickerson, K. H. Sandhage, R. R. Naik, Chem. Rev. 2008, 108, 4935-4978.

[5] For examples of the generation of AgNPs and Ag nanostructures in general using peptidic scaffolds, see: a) A. Mantion, A. G. Guex, A. Foelske, L. Mirolo, K. M. Fromm, M. Painsi, A Taubert, Soft Matter 2008, 4, 606-617; b) D. Gottlieb, S. A Morin, S. Jin, R. T. Raines, J. Mater. Chem. 2008, 18, 3865-3870; c) M. G. Ryadnov, Angew. Chem. 2007, 119, 987-990; Angew. Chem. Int. Ed. 2007, 46, 969-972; d) K. Huber, T. Witte, J. Hollmann, S. Keuker-Baumann, J. Am. Chem. Soc. 2007, 129 , 1089-1094; e) S. Si, T. K. Mandal, Chem. Eur. J. 2007, 13, 3160 3168; f) P. P. Bose, M. G. B. Drew, A. Banerjee, Org. Lett. 2007, 9, 2489-2492; g) S. Anil Kumar, M. K. Abyaneh, S. W. Gosavi, S. K. Kulkarni, R. Pasricha, A. Ahmad, M. I. Khan, Biotechnol. Lett. 2007, 29, 439-445; h) L. Fabris, S. Antonello, L. Armelao, R. L. Donkers, F. Polo, C. Toniolo, F. Maran, J. Am. Chem. Soc. 2006, 128, 326-336; i) R. C. Doty, T. R. Tshikhudo, M. Brust, D. G. Fernig, Chem. Mater. 2005, 17, 4630-4635; j) Z. Wang, R. Lévy, D. G. Fernig, M. Brust, Bioconjugate Chem. 2005, 16, $497-$ $500 ;$ k) E. Dujardin, C. Peet, G. Stubbs, J. N. Culver, S. Mann, Nano Lett. 2003, 3, 413-417; 1) J. M. Slocik, D. W. Wright, Biomacromolecules 2003, 4, 1135-1141; m) L. Yu, I. A. Banerjee, H. Matsui, J. Am. Chem. Soc. 2003, 125, 14837-14840; n) M. Reches, E. Gazit, Science 2003, 300, 625-627; o) J. M. Slocik, J. T. Moore, D. W. Wright, Nano Lett. 2002, 2, 169-173.

[6] a) J. Xie, J. Y. Lee, D. I. C. Wang, Y. P. Ting, Nano 2007, 1, 429439; b) S. Si, R. R. Bhattacharjee, A. Banerjee, T. K. Mandal, Chem. Eur. J. 2006, 12, 1256-1265; c) S. Ray, A. K. Das, A Banerjee, Chem. Commun. 2006, 2816-2818; d) S. Bhattacharya, A. K. Das, A. Banerjee, D. Chakravorty, J. Phys. Chem. B 2006, 110, 10757-10761.

[7] For the use of parallel combinatorial peptide libraries, see: R. Lévy, N. T. K. Thanh, R. C. Doty, I. Hussain, R. J. Nichols, D. J. Schiffrin, M. Brust, D. G. Fernig, J. Am. Chem. Soc. 2004, 126 , 10076-10084.

[8] For the use of phage display libraries, see: a) F. Baneyx, D. T. Schwartz, Curr. Opin. Biotechnol. 2007, 18, 312-317; b) A. R. Bassindale, A. Codina-Barrios, N. Frascione, P. G. Taylor, Chem. Commun. 2007, 2956-2958; c) R. R. Naik, S. E. Jones, C. J.
Murray, J. C. McAuliffe, R. A. Vaia, M. O. Stone, Adv. Funct. Mater. 2004, 14, 25-30; d) R. R. Naik, S. J. Stringer, G. Agarwal, S. E. Jones, M. O. Stone, Nat. Mater. 2002, 1, 169-172.

[9] For the use of split-and-mix libraries to identify selective intermolecular interactions or catalysts, see: a) N. Srinivasan, J. D. Kilburn, Curr. Opin. Chem. Biol. 2004, 8, 305-310; b) J. D. Revell, H. Wennemers, Curr. Opin. Chem. Biol. 2007, 11, 269278.

[10] a) M. H. J. Ohlmeyer, R. N. Swanson, L. W. Dillard, J. C. Reader, G. Asouline, R. Kobayashi, M. H. Wigler, W. C. Still, Proc. Natl. Acad. Sci. USA 1993, 90, 10922-10926; b) H. P. Nestler, P. Bartlett, W. C. Still, J. Org. Chem. 1994, 59, $4723-$ 4724.

[11] a) Á. Furka, F. Sebestyén, M. Asgedom, G. Dibô, Int. J. Pept. Protein Res. 1991, 37, 487-493; b) K. S. Lam, S. E. Salmon, E. M. Hersh, V. J. Hruby, W. M. Kazmierski, R. J. Knapp, Nature 1991, 354, $82-84$.

[12] A total of at least five theoretical copies of the library was used per screening in order to ensure the presence of each library member; a) K. Burgess, A. I. Liaw, N. Y. Wang, J. Med. Chem. 1994, 37, 2985 - 2987; b) P.-L. Zhao, R. Zambias, J. A. Bolognese, D. Boulton, K. T. Chapman, Proc. Natl. Acad. Sci. USA 1995, 92, $10212-10216$

[13] As the beads were not continuously agitated upon irradiation with light, several of the beads are colored on only one half.

[14] In control experiments with a tripeptide library of the general structure Ac-AA3-AA2-AA1-resin with no linkers between the amino acids, AgNP formation was not observed under identical conditions. This experiment further supports the importance of the rigid linker. For the importance of turn-inducing linkers in peptide binding to metal ions other than $\mathrm{Ag}^{+}$, see: M. B. Francis, N. S. Finney, E. N. Jacobsen, J. Am. Chem. Soc. 1996, 118, $8983-$ 8984.

[15] All possible diastereoisomers of peptides 2a and 3a were examined and showed essentially the same results, which demonstrates that the absolute configuration of the amino acids is of minor importance for activity.

[16] Negative control experiments with peptides that were not hits in the combinatorial assay (e.g., Ac-Tyr-Gly-Tyr-TG) did not form AgNPs under identical conditions.

[17] M. Conza, H. Wennemers, Chem. Commun. 2003, 866-867. For details on the $\mathrm{Ag}^{+}$ion uptake studies see the Supporting Information. 